\title{
ANALISIS KELAYAKAN MESIN PENGERING KERIPIK KENTANG
}

\author{
M. Adhi Prasnowo ${ }^{1 *}$, Shafiq Nurdin ${ }^{2}$ \\ ${ }^{1}$ Program Studi Teknik Industri, Universitas Maarif Hasyim Latif \\ ${ }^{2}$ Program Studi Teknik Mesin, Politeknik Unisma \\ Email : prasnowoadhi@dosen.umaha.ac.id
}

\begin{abstract}
Batu City is a tourist destination for domestic and foreign tourists because it have variety of tourist destinations that have been managed properly. The development of tourist destinations that increases rapidly, making the businessmen souvenirs typical of Batu City growing. It is also felt by potato chips entrepreneurs, who are experiencing increased demand. But entrepreneurs increasingly difficult to increase the amount of productivity, because the technology used to produce potato chips is still simple. So that can not meet the needs of a very high market. This study aims to determine the economic viability of potato chips dryer. The method used in this research is Net Present Value (NPV) and Internal Rate of Return (IRR). Based on the financial feasibility analysis of potato chips dryer machine using electric energy is feasible to be implemented because the value of NPV is greater than zero which is IDR. 5.233 .433 and IRR value $22 \%$ greater than the current interest rate of $12 \%$ with the project period of 5 years.
\end{abstract}

Keyword: feasibility study, dryer machine, potato chips

\section{PENDAHULUAN}

Kota Batu merupakan daerah tujuan wisata bagi wisatawan domestik maupun mancanegara, karena memiliki berbagai macam pesona alam yang telah dikelola dengan baik. Perkembangan objek wisata yang semakin pesat, membuat para pengusaha oleh-oleh khas Kota Batu semakin berkembang. Hal itu juga sangat dirasakan oleh pengusaha keripik kentang, yang mengalami perkembangan yang sangat pesat. Bahkan menurut Dinas Perindustrian dan Perdagangan Provinsi Jawa Timur (2011) salah satu produk unggulan Kota Batu adalah keripik kentang.

Namun permintaan pasar yang semakin meningkat membuat pengusaha keripik kentang berusaha untuk meningkatkan omset penjualannya. Akan tetapi pengusaha semakin sulit untuk meningkatkan jumlah produktivitasnya, hal itu dikarenakan teknologi yang digunakan untuk memproduksi keripik kentang masih sederhana. Sehingga tidak bisa mencukupi kebutuhan pasar yang sangat tinggi. Yang menjadi masalah adalah pada proses pengeringan keripik kentang, karena pada saat musim kemarau sinar matahari dapat mengeringkan keripik dengan maksimal, akan tetapi jika musim penghujan maka kesulitan dalam melakukan pengeringan. Karena jika dijemur dan tidak kering sampai dua hari, maka akan menurunkan kualitas keripik kentang. Bahakan akan membuat produk tersebut menjadi terkena jamur dan tidak layak untuk proses selanjutnya.

Untuk mempertahankan kualitas keripik kentang, bisa dilakukan dengan cara pengeringan. Dengan pengeringan, kentang dapat disimpan lebih lama. Prinsip pengeringan kentang adalah upaya menguapkan air karena ada perbedaan kandungan uap air antara udara dan bahan yang dikeringkan (Aviara, 2010). Udara mempunyai kandungan uap air yang lebih kecil daripada bahan yang dikeringkan. Salah satu faktor yang dapat mempercepat pengeringan adalah angin atau udara yang 
mengalir. Dengan adanya aliran udara maka udara yang sudah jenuh dapat diganti dengan udara kering sehingga proses pengeringan berjalan terus. Pengeringan dapat dilakukan dengan dua cara, yaitu pengering alami dan pengeringan mekanik.

Pengeringan keripik kentang dengan alat pengering mekanik dapat menjamin mutu yang baik daripada pengeringansecara alami. Pada dasarnya alat pengering mekanik diciptakan agar pengeringan dapat dilakukan kapan saja. Selain itu diharapkan dengan alat ini dapat mempercepat waktu pengeringandan dengan kualitas serta kuantitas hasil yang baik. Pengolahan keripik kentang dengan cara pengeringan tradisional dilakukan dengan cara menjemur di bawah sinar matahari. Pada musim penghujan pengolahan keripik kentang cara tradisional menghasilkan keripik yang kurang bagus karena kurang berwarna cerah dan kurang menarik, yaitu kecoklatan. Warna kentang yang baik adalah kuning kecoklatan. Namun pengeringan secara alami memerlukan biaya yang relatif kecil, tapi memerlukan waktu yang lebih lama dibanding dengan pengeringan secara mekanik.

Dari permasalahan diatas dapat dirumuskan suatu masalah yaitu, menganalisis kelayakan mesin pengering keripik kentang dengan pendekatan engineering economy. Dalam penelitian ini mesin pengering keripik kentang yang dianalisis adalah mesin pengering keripik kentang dengan menggunakan energi listrik. Tujuan analisis kelayakan ini adalah untuk mengetahui keuntungan serta kelayakan yang didapat dari investasi mesin ini.

\section{METODE}

Penelitian ini menggunakan metode Net Present Value (NPV) dan Internal Rate of Return (IRR). Sehingga setelah dilakukan analisis ekonomi akan menghasilkan keputusan, apakah mesin pengering keripik kentang layak untuk dijalankan atau tidak.

Menurut Suad (2005), metode Net Present Value (NPV) merupakan besarnya selisih antara nilai sekarang investasi dengan nilai sekarang penerimaanpenerimaan kas bersih di masa yang akan datang. Untuk meghitung nilai sekarang tersebut perlu ditentukan dahulu tingkat bunga yang dianggap relevan sebagai dasar pertimbangan yaitu suku bunga deposito yang berlaku di bank.

NPV dapat diperoleh dengan menggunkahan rumus sebagai berikut (Yakop Ibrahim, 2003) :

$$
N P V=\sum_{i=1}^{n} \frac{N B i}{(1+i)^{n}}
$$

Dimana :

NPV : Net Present Value

NB : Net Benefit $=$ benefit-cost

i : Discount factor

N : Tahun (waktu)

Kriteria penilaian hasil perhitungan:

- NPV > 0 (nol), maka usaha layak dilaksanakan

- NPV < 0 (nol), maka usaha tidak layak dilaksanakan

- NPV = 0 (nol), maka usaha tersebut berada dalam keadaan BEP dalam bentuk present value

Menurut E. Paul De Garmo (1999) Internal Rate Of Return (IRR) adalah suatu metode yang mempertimbangkan tingkat bunga eksternal terhadap suatu proyek yang pada tingkat bunga ini arus kas netto yang dihasilkan oleh perusahaan/proyek selama umurnya dapat diinvestasikan kembali. IRR dapat diperoleh dengan menggunakan rumus sebagai berikut:

$\sum_{k=0}^{N} E_{k}(P / F, \in \%, k)(F / P, i \%, N)=\sum_{k=0}^{N} R_{k}(F / P, \in \%, N-k)$ dimana :

$R_{k}=$ Kelebihan penerimaan terhadap penghasilan dalam periode $\mathrm{k}$.

$E_{k}=$ kelebihan pengeluaran terhadap penerimaan dalam periode $\mathrm{k}$.

$N=$ Umur proyek. 
$\epsilon=$ tingkat reinvestasi eksternal per periode.

IRR > tingkat keuntungan yang diisyaratkan, proyek diterima

IRR < tingkat keuntungan yang diisyaratkan, proyek ditolak.

\section{HASIL DAN PEMBAHASAN}

Meskipun industri berskala menengah

ke atas untuk memproduksi keripik kentang juga hadir di Batu, namun industri kripik skala rumah tangga di daerah itu tetap bertahan. Ini didukung pasar yang mulai membaik. Harga penjualan produk ini juga relatif tinggi."Industri keripik kentang yang makin banyak itu makin baik. Pemasarannya sekarang tidak lagi sulit seperti dahulu. Keripik kentang menjadi oleh-oleh khas Batu, selain apel yang populer sejak lama. Namun, kekhasan keripik kentang buatan Batu seolah-olah hanya dikenal masyarakat lapisan ekonomi menengah ke atas. Sebab, harga keripik kentang kini $\mathrm{Rp} 80.000$ per kilogram $(\mathrm{kg})$ untuk kualitas keripik kentang super. Yang paling murah Rp 40.000 per kg. Harga keripik kentang dipengaruhi oleh kualitasnya. Keripik kentang termahal berukuran besar, dan setelah digoreng berwarna putih bersih. Keripik kentang yang termurah berukuran acak, tetapi kecilkecil dan berwarna putih kecoklatan.

Produk ini menjadi banyak disukai karena kadar kolesterol kentang tergolong paling rendah, namun memberi kalori yang cukup (Kolasa, 1993). Pembuatan keripik kentang semuanya berbahan baku lokal dari daerah Batu. Agen penjualnya sekarang selalu menyetor kentang mentah ke rumahnya. Setiap bulan membutuhkan 2,1 ton kentang mentah, dan setiap hari jumlah kentang mentah yang diolah menjadi kripik rata-rata $70 \mathrm{~kg}$. Penyusutan bobot kentang menjadi keripik kentang cukup tinggi. Dari setiap $10 \mathrm{~kg}$ kentang, setelah diproses hanya menghasilkan satu kilogram keripik. Ini pula yang membuat harga keripik kentang tergolong mahal. Harga bahan mentah kentang untuk musim hujan dan musim kemarau juga berbeda. Pada musim hujan harga kentang Rp 2.500 per $\mathrm{kg}$, tetapi pada musim panas harga kentang Rp 4.000 per kg. Uniknya, perbedaan harga bahan mentah itu tidak mempengaruhi harga keripik kentang. Harga yang tetap sama juga berlaku untuk keripik kentang yang belum matang atau sudah matang. Sebab, satu kg keripik kentang mentah, setelah digoreng bobotnya naik menjadi 1,2 kg. Pengeringan keripik kentang dari industri ini memanfaatkan panas matahari. Masa pengeringan terbaik, dengan panas matahari yang optimal mencapai tiga hari. Akan tetapi jika kurang dari tiga hari, maka keripik kentang akan berwarna putih kecoklatan dan kurang renyah.

Dalam analisis data ini akan dilakukan analisis terhadap alternatif mesin pengering yaitu mesin pengering kripik kentang energi listrik. Investasi mesin yang akan dijalankan oleh perusahaan adalah investasi mesin pengering keripik kentang dengan menggunakan listrik. Dalam 1 tahun industri keripik kentang memproduksi selama 1 tahun penuh dengan besar suku bunga $12 \%$. Total cost (TC) adalah total biaya yang dikeluarkan untuk membeli mesin pengering keripik kentang yaitu Rp 20.000.000.

Metode Net Present Value (NPV) digunakan untuk menentukan selisih jumlah arus kas masuk dengan jumlah arus kas keluar berdasarkan nilai sekarang. Berikut tabel perhitungan NPV.

Tabel 1 Analisis Net Present Value

\begin{tabular}{cccc}
\hline Thn & $\begin{array}{c}\text { Net Cash } \\
\text { Flow }\end{array}$ & $\begin{array}{c}\text { Present } \\
\text { Value }\end{array}$ & $\begin{array}{c}\text { Discounted } \\
\text { Cash Flow }\end{array}$ \\
\hline 1 & 7.000 .000 & 0,8929 & 6.250 .000 \\
2 & 7.000 .000 & 0,7972 & 5.580 .357 \\
3 & 7.000 .000 & 0,7118 & 4.982 .462 \\
4 & 7.000 .000 & 0,6355 & 4.448 .627 \\
5 & 7.000 .000 & 0,5674 & 3.971 .988 \\
\hline
\end{tabular}

Berdasarkan perhitungan diatas, dapat diketahui bahwa NPV pada tingkat bunga $12 \%$ adalah positif sebesar Rp. 5.233.433. Dengan NPV positif dapat disimpulkan 
bahwa berdasarkan analisis NPV maka rencana penggunaan mesin pengering keripik kentang dengan menggunakan energi listrik dapat diterima dan layak untuk dilaksanakan.

Metode IRR digunakan untuk menentukan pada tingkat bunga berapa agar nilai NPV dari proyek sama dengan nol. Apabila tingkat bunga sekarang sama dengan nilai IRR maka NPV dari proyek sama dengan nol. Bila nilai IRR lebih kecil dari tingkat bunga, berarti NPV lebih kecil nol. Berdasarkan hasil perhitungan dapat diketahui bahwa IRR dari investasi ini adalah sebesar $22 \%$. Nilai IRR lebih besar dari tingkat bunga sekarang yaitu $12 \%$, sehingga nilai NPV lebih besar dari nol (positif). Dari analisis diatas dapat disimpulkan bahwa penggunaan mesin pengering keripik kentang dengan menggunakan energi listrik dapat diterima dan layak untuk dilaksanakan.

KESIMPULAN

Berdasarkan analisis kelayakan keuangan mesin pengering keripik kentang dengan menggunakan energi listrik layak untuk dilaksanakan karena nilai NPV lebih besar dari pada nol yaitu Rp. 5.233.433 dan nilai IRR $22 \%$ lebih besar dari tingkat bunga sekarang yaitu $12 \%$ dengan masa proyek 5 tahun.

\section{DAFTAR PUSTAKA}

Agus S, 2006. Pengeringan Pakan Pallet dengan Alat pengering Buatan, Temu Teknis Nusional Tenaga Fungsional Pertanian, Balai penelitian Ternak Bogor.

Alwi, Suryanti, 2006. Perancangan Mesin Pengering Ikan Dengan Menggunakan Kolektor Surya Plat Datar, Jurusan Teknik Industri, Universitas Kristen Petra

Aviara, N.A., J.C. Igbeka and L.M. Nwokocha. 2010. Physicochemical Properties of Sorghum (Sorghum Bicolor L. Moench) Starch as
Affected by Drying Temperature. Agricultural Engineering International: CIGR Journal Vol. 12, No. 2, Page 85-98.

De Garmo, E.P.; W.G. Sulivan; J.A. Bontidelli, Engineering Economy, 10th ed., Macmilan, New York.

Dinas Perindustrian dan Perdagangan Provinsi Jawa Timur, 2011, Potensi Produk Unggulan Kabupaten/Kota se Jawa Timur, Forum Komunikasi Perencanaan Industri.

Husnan, Suad, 2005. Study Kelayakan Proyek,UPP STIMIK YKPN, Yogyakarta.

Husein Umar, Studi Kelayakan Bisnis: Teknik Menganalisis Kelayakan Rencana Bisnis Secara Komprehensif, Edisi ke-2, Gramedia Pustaka Utama

Ibrahim Yacob, H. M. Studi Kelayakan Bisnis, Edisi Revisi, Penerbit PT. Rineka Cipata, Jakarta, 2003.

Kolasa KM. 1993. The potato and human nutrition. American Potato Journal 70(5), 375-383

Maria, 2010. Net Present Value With A Spreadsheet, Journal of efense Resources Management.

Pujawan, N, 2013, Ekonomi Teknik, Edisi Kedua, PT. Gunawidya, Jakarta.

Susanti, 2012. Analisis Kelayakan Investasi Perbaikan Sarana Produksi Pada Home Industri Kerupuk Bawang, Teknik Industri, Universitas 17 Agustus 1945 Banyuwangi

Sutrisno, Budi R, 2010. Rekayasa Mesin Pengering Padi Bahan Sekam (BBM) Kapsitas 10T Terintegrasi Untuk Meningkatkan Nilai Ekonomi Penggilingan Padi Dilahan Pasang Surut Sumatra Selatan, Jurnal Pembangunan Manusia edisi 6.

Thuesen, G.J., Fabrycky, W.J.2001. Engineering Economy, 9th ed., Prentice Hall Inc., New Jersey. 